\title{
Synthesis and Release of Catecholamines by the Cat Carotid Body in Vitro: Effects of Hypoxic Stimulation
}

\author{
R. RIGUAL, E. GONZALEZ, C. GONZALEZ and S. FIDONE \\ Departamento de Fisiologia y Bioquimica, Facultad de Medicina, Valladolid (Spain) and Department of Physiology, \\ School of Medicine, University of Utah, Salt Lake City, UT (U.S.A.)
}

(Accepted October 9th, 1985)

Key words: carotid body - chemoreceptor - hypoxia - catecholamine - dopamine release — carotid sinus nerve activity

\begin{abstract}
The role of catecholamines (CAs) in cat carotid body chemoreception has been controversial. On the basis of pharmacological experiments, it would appear that endogenous dopamine (DA) may act either as an inhibitory or excitatory transmitter. Neurochemical studies on the effects of natural stimulation on the release of carotid body CAs in the cat have also been inconclusive. In the present study, we have characterized the synthesis and release of CAs in the in vitro cat carotid body preparation in response to different levels of hypoxic stimulation and have correlated these measures with the chemosensory activity of the carotid sinus nerve. The synthesis of $\left[{ }^{3} \mathrm{H}\right] \mathrm{DA}$ and $\left[{ }^{3} \mathrm{H}\right]$ norepinephrine was linear for at least $4 \mathrm{~h}$ in carotid bodies incubated with their natural precursor [ $\left.{ }^{3} \mathrm{H}\right]$ tyrosine. Synthesis of both $\left[{ }^{3} \mathrm{H}\right] \mathrm{CAs}$ plateaued when the $\left[{ }^{3} \mathrm{H}\right]$ tyrosine concentration in the media reached $40 \mu \mathrm{M}$, which is a concentration similar to that found in cat plasma. Exposure of the animals to an atmosphere of $10 \% \mathrm{O}_{2}$ in $\mathrm{N}_{2}$ for $3 \mathrm{~h}$ prior to removal and incubation of the carotid bodies with $\left[{ }^{3} \mathrm{H}\right]$ tyrosine resulted in an approximately $100 \%$ increase in the rate of $\left[{ }^{3} \mathrm{H}\right] \mathrm{DA}$ synthesis but no change in $\left[{ }^{3} \mathrm{H}\right]$ norepinephrine synthesis. This selective increase in $\left[{ }^{3} \mathrm{H}\right] \mathrm{DA}$ synthesis was not detected when $\left[{ }^{3} \mathrm{H}\right]$ dihydroxyphenylalanine was used as precursor. Carotid bodies first incubated with $\left[{ }^{3} \mathrm{H}\right]$ tyrosine and later superfused with solutions equilibrated with different gas mixtures $(0-$ $100 \% \mathrm{O}_{2}$ in $\mathrm{N}_{2}$ ) exhibited an increase in [ $\left.{ }^{3} \mathrm{H}\right] \mathrm{DA}$ release and carotid sinus nerve discharge which were inversely related to the oxygen concentration. This relationship was strongest for the weaker stimuli (between $50 \%$ and $20 \% \mathrm{O}_{2}$ in $\mathrm{N}_{2}$ ), where both nerve activity and $\left[{ }^{3} \mathrm{H}\right] \mathrm{DA}$ release increased almost in parallel. With lower oxygen concentrations $\left(10 \% \mathrm{O}_{2}\right.$ and $0 \% \mathrm{O}$, equilibrated solutions), the increase in the release of $\left[{ }^{3} \mathrm{H}\right] \mathrm{DA}$ was proportionally greater than the increase in carotid sinus nerve discharge. Our results demonstrate that hypoxic stimulation increases both the rate of synthesis and release of DA in the cat carotid body. Although the precise role of DA in this chemoreceptor organ is presently unknown, our findings suggest that this biogenic amine plays a direct role in generating or controlling the electrical activity in the carotid sinus nerve.
\end{abstract}

\section{INTRODUCTION}

The mammalian carotid body is an arterial chemoreceptor organ activated by low $\mathrm{p}_{\mathrm{a}} \mathrm{O}_{2}$, low $\mathrm{pH}$ and high $\mathrm{p}_{\mathrm{a}} \mathrm{CO}_{2}$ (ref. 21). Structurally, the receptor complex is formed by clusters of two types of cells, the type I and type II cells; the clusters lie within a supporting connective tissue matrix containing a dense capillary net ${ }^{24,41}$. Sensory fibers of the carotid sinus nerve (CSN) penetrate these cell clusters to end in synaptic apposition with type I cells, which are considered to be preneural (receptor) elements. Two perennial issues pertaining to arterial chemorecep- tion, concern first, whether the type I cells are in fact the sole transducer elements in this sensory receptor, and, second, what are the functions of the several putative neurotransmitters contained in these cells (dopamine (DA), norepinephrine (NE), acetylcholine $(\mathrm{ACh})$, Leu- and Met-enkephalin, substance P (SP) and serotonin (5-HT); for discussion, see refs. 2, 10. $12-14$ and 22).

In recent years, particular attention has focused on the role of the catecholamines (CAs), most notably $\mathrm{DA}$, in the chemoreception process (for review of these studies, see ref. 12). The two general experimental approaches which have been used in these

Correspondence: R. Rigual, Departamento de Fisiologia y Bioquimica, Facultad de Medicina, Valladolid, Spain. 
studies are: (1) the correlation of neurochemical changes in the metabolism of carotid body CAs (e.g. synthesis, release, receptor localization. (tc) with changes in chemoreceptor activity, and (2) the pharmacological characterization of the effects of catecholaminergic agonists and antagonists on CSN discharge.

In the cat, these neurochemical studies disagree in regard to the effects of chemoreceptor stimulation on CA content of the carotid body. Thus, Zapata et al. ${ }^{44}$ showed that prolonged severe hypoxic stimulation in vivo $\left(3 \mathrm{~h} ; 5 \% \mathrm{O}_{2}\right.$ in $\mathrm{N}_{2}$, anesthetized cat ) or in vitro ( $2 \mathrm{~h}$ in anoxia) failed to modify carotid body CAs. On the other hand, Mills and Slotkin ${ }^{2 x}$ reported a marked decrease in CA content of the organ after only $40 \mathrm{~min}$ of mild hypoxia $\left(14 \% \mathrm{O}_{2}\right.$ in $\left.\mathrm{N}_{2}\right)$. Fitzgerald et al. ${ }^{15}$ also found a decrease in DA content in $a$-methyl-p-tyrosine treated cats after $30 \mathrm{~min}$ of severe hypoxia $\left(\mathrm{p}_{\mathrm{a}} \mathrm{O}_{2}=25\right.$ torr). Finally, Starlinger et al. ${ }^{37}$ observed that $1 \mathrm{~h}$ of hypoxia $\left(16 \% \mathrm{O}_{2}\right)$ produced only a marginal decrease in NE content of the carotid body.

Studies aimed at characterizing the pharmacological actions of exogenously applied DA and its agonists and antagonists have also produced some confounding results. A common finding from these investigations has been that DA may behave either as an excitatory or inhibitory agent in the carotid body, depending upon the dose of the administered agent ${ }^{43}$, the animal species studied ${ }^{2 y}$. and in particular whether the organ is studied in vivo or in vitro (e.g. compare ref. 6 vs 29 and ref. 7 vs 33). However, as pointed out by McQueen ${ }^{27}$, such conflicting pharmacological studies need not reflect real differences in the actions of DA in these different preparations or species but may simply result from uncontrolled experimental variables such as vascular effects in vivo or perhaps receptor desensitization in vitro, etc. This explication notwithstanding, it is evident that the function of CAs in cat carotid body chemoreception is not clear.

It is well recognized that the actions of a given putative neurotransmitter are reflected in its metabolic response to natural stimulation 1,26,34. Consequently, the present study was undertaken to characterize the effects of hypoxic stimulation on the synthesis of CAs by the cat carotid body and to monitor directly the release of CAs from this organ as a function of the in- tensity of hypoxic stimulation and the electrical activity of the carotid sinus nerve

\section{MATERIALS AND METHODS}

Surgical procedures. All experiments were performed with adult cats $(2-3.5 \mathrm{~kg})$ anesthetized with sodium pentobarbital ( $30-40 \mathrm{mg} / \mathrm{kg}$. i.p.: Sigma). The animals were tracheostomized and artificially ventilated with a Palmer respirator $(30 \mathrm{ml}: 25$ stro$\mathrm{kes} / \mathrm{min}$ ). After surgically exposing the area of the carotid bifurcation, the carotid body (in some experiments, with the CSN attached) was quickly removed and placed in a clear Lucite chamber filled with icecold $100 \% \mathrm{O}_{2}$-equilibrated Tyrode solution (in $\mathrm{mM}$ ): $\mathrm{NACl}, 112 ; \mathrm{KCl}, 4.7: \mathrm{CaCl}_{2}, 2.2 ; \mathrm{MgCl}_{2}, 1.1$; Na-glutamate, 44; N-2-hydroxyethylpiperazine- $\mathrm{N}$ 2-ethanesulfonic acid (HEPES), 5; glucose. 5.5; the $\mathrm{pH}$ was adjusted to 7.40 with $1 \mathrm{~N} \mathrm{NaOH}$. Using a dissecting microscope equipped with cold illumination, the carotid body was cleaned of surrounding loose connective tissue, capsule and periglomerular vascular plexus. For chronic denervation experiments, the CSN or the superior cervical ganglion was removed unilaterally under aseptic conditions $12-15$ days prior to removal of the carotid body; the contralateral organ then served as control.

Finally, in another group of experiments, cats were exposed for a 3 -h period in a chamber ${ }^{13}$ continuously flushed with $10 \% \mathrm{O}_{2}$ in $\mathrm{N}_{2}$ just prior to removal of the carotid bodies; control animals for this hypoxic' group were placed in the chamber to breathe room air. The animals were ventilated with the corresponding gas mixture during surgery.

Catecholamine synthesis. Carotid bodies were placed in mini vials containing $0.5 \mathrm{ml}$ of $100 \% \mathrm{O}_{2}-$ equilibrated Tyrode solution. which also contained $100 \mu \mathrm{M}$ of the tyrosine hydroxylase cofactor, 6-methyltetrahydropterine (6- $\mathrm{MPH}_{4}$; Sigma), $1 \mathrm{mM}$ ascorbic acid and $10-80 \mu \mathrm{M}\left[{ }^{3} \mathrm{H}\right]$ tyrosine $\left(\left[2,6{ }^{3} \mathrm{H}\right]\right.$ tyrosine, $1 \mathrm{Ci} / \mathrm{mmol}$; Amersham). Incubation proceeded at $37^{\circ} \mathrm{C}$ in a metabolic shaker (New Brunswick) at 75 rpm for $0.5-4 \mathrm{~h}$. In some experiments. $\left[{ }^{3} \mathrm{H}\right] \mathrm{dihy}-$ droxyphenylalanine, ([ $\left.{ }^{3} \mathrm{H}\right] \mathrm{DOPA} ; 10, u \mathrm{M} ; 1 \mathrm{Ci}$ mmol, Amersham) was used as precursor for $\left[{ }^{3} \mathrm{H}\right] \mathrm{CA}$ synthesis, and the tyrosine hydroxylase cofactor was omitted. At the end of the incubation period, the tissues were washed in $10 \mathrm{ml}$ of ice-cold $100 \% \mathrm{O}_{2}$-equi- 
librated Tyrode solution for $5 \mathrm{~min}$ to remove excess labelled precursor, after which the samples were processed for analysis. Carotid bodies were weighed on a Cahn electrobalance provided with a humidified chamber, homogenized and the $\left[{ }^{3} \mathrm{H}\right] \mathrm{CAs}$ separated by high-voltage paper electrophoresis. As previously described ${ }^{11}$, the paper strips were scanned for radioactivity against standard strips containing $\left[{ }^{3} \mathrm{H}\right]$ tyrosine, $\left[{ }^{3} \mathrm{H}\right] \mathrm{DA}$ and $\left[{ }^{3} \mathrm{H}\right] \mathrm{NE}$. The areas containing these substances were combusted in a sample oxidizer and counted in a scintillation counter ( $40 \%$ counting efficiency). Results here are expressed as $\mathrm{nmol} / \mathrm{g}$ tissue (mean cat carotid b.wt., $559 \pm 219$ (S.D.) $\mu \mathrm{g}$; $\mathrm{n}=70$ ). In other experiments performed at the Department of Physiology in Valladolid, the CA levels were determined by thin-layer chromatography, according to the method of Fleming and Clark ${ }^{16}$, except that the plates were stained with a ferricyanidebased reagent $(0.05 \%$ potassium ferricyanide $+1 \%$ ferrychloride) to minimize quenching. The colored spots were scraped off, eluted by vigorous shaking ( 1 $\min$ ) in $1 \mathrm{ml}$ of $1 \mathrm{~N} \mathrm{HCl}$ and counted with $30 \%$ efficiency. Results are expressed as pmol $\mathrm{CA}$ /carotid body.

Catecholamine release. These experiments were carried out as described previously ${ }^{14}$. Briefly, carotid bodies were incubated for $3 \mathrm{~h}$ with $\left[{ }^{3} \mathrm{H}\right]$ tyrosine of high specific activity (20-40 Ci/mmol; Amersham) to label tissue CA stores. At the end of the incubation period, the organs were mounted in a superfusion chamber which allowed simultaneous recording of CSN activity and collection of the superfusates containing the released labelled CAs. Collection periods (see Fig. 1) were grouped into 'stimulus cycles', with each cycle consisting of a 5 -min control period (superfusion with $100 \% \mathrm{O}_{2}$-equilibrated Tyrode), followed by a 5 -min stimulus period (superfusion with Tyrode equilibrated with different low $\mathrm{O}_{2}$-gas mixtures; 'stim' in Fig. 1), which was followed in turn by 4 post-stimulus periods of 5 or 10 min duration (superfusion again with $100 \% \quad \mathrm{O}_{2}$-equilibrated Tyrode). The total duration of a single stimulus cycle was $45 \mathrm{~min}$, and each experiment consisted of 3-5 consecutive cycles. CSN action potentials were amplified for display on an oscilloscope and led through a window discriminator to a counter-printer. The superfusates from each period were collected in vials containing a carrier mixture consisting of $0.3 \mathrm{M}$ ace-
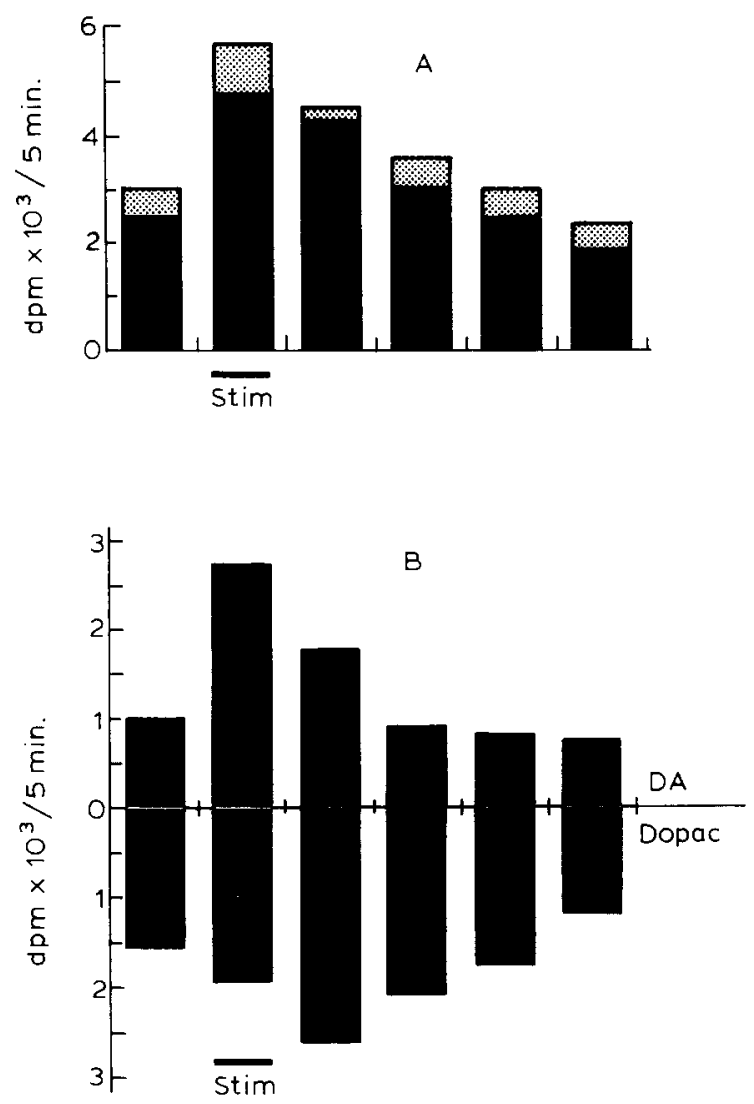

Fig. 1. A: release of $\left[{ }^{3} \mathrm{H}\right] \mathrm{CAs}$ from the cat carotid body during a single 'stimulus cycle'; and B: thin-layer chromatographic (TLC) identification of the released material. In both A and B, the left-most bar represents the control period $(5 \mathrm{~min})$, the bar labelled Stim corresponds to the stimulus period $(5 \mathrm{~min})$, and the remaining bars are for poststimulus periods of $5,10,10$ and 10 min duration. A shows the radioactivity present in the alumina eluates; the solid portion of each bar represents the radioactivity identified by TLC as $\left[{ }^{3} \mathrm{H}\right] \mathrm{DA}+\left[{ }^{3} \mathrm{H}\right] \mathrm{DOPAC}$, while the stippled portion represents unidentified radiolabelled compounds. B shows $\left[{ }^{3} \mathrm{H}\right] \mathrm{DA}$ (upper bars) and $\left[{ }^{3} \mathrm{H}\right] \mathrm{DOPAC}$ (lower bars) present in the alumina eluates from the corresponding. fractions of the stimulus cycle. Owing to the small rate of $\left[{ }^{3} \mathrm{H}\right] \mathrm{NE}$ synthesis by the carotid bodies, $\left[{ }^{3} \mathrm{H}\right] \mathrm{NE}$ or its catabolites were not measured in these experiments.

tic acid, $1.0 \mathrm{mM}$ ascorbic acid and $100 \mu \mathrm{M}$ unlabelled $\mathrm{DA}$, final $\mathrm{pH}$ 3.6. The samples were then adsorbed with alumina at $\mathrm{pH} 8.6$ and eluted with $1 \mathrm{~N} \mathrm{HCl}$ to recover $\left[{ }^{3} \mathrm{H}\right] \mathrm{CAs}$ and $\left[{ }^{3} \mathrm{H}\right]$ catechol catabolites. In some experiments, the $1 \mathrm{~N} \mathrm{HCl}$ eluates were dried in a vacuum concentrator (Savant) and thin-layer chromatographed ${ }^{16}$. Since most of the radioactivity present in the eluates could be identified as $\left[{ }^{3} \mathrm{H}\right] \mathrm{DA}+\mathrm{di}-$ hydroxyphenylacetic acid ([$\left.\left.{ }^{3} \mathrm{H}\right] \mathrm{DOPAC}\right)$ (Fig. 1), the alumina eluates in most experiments were direct- 

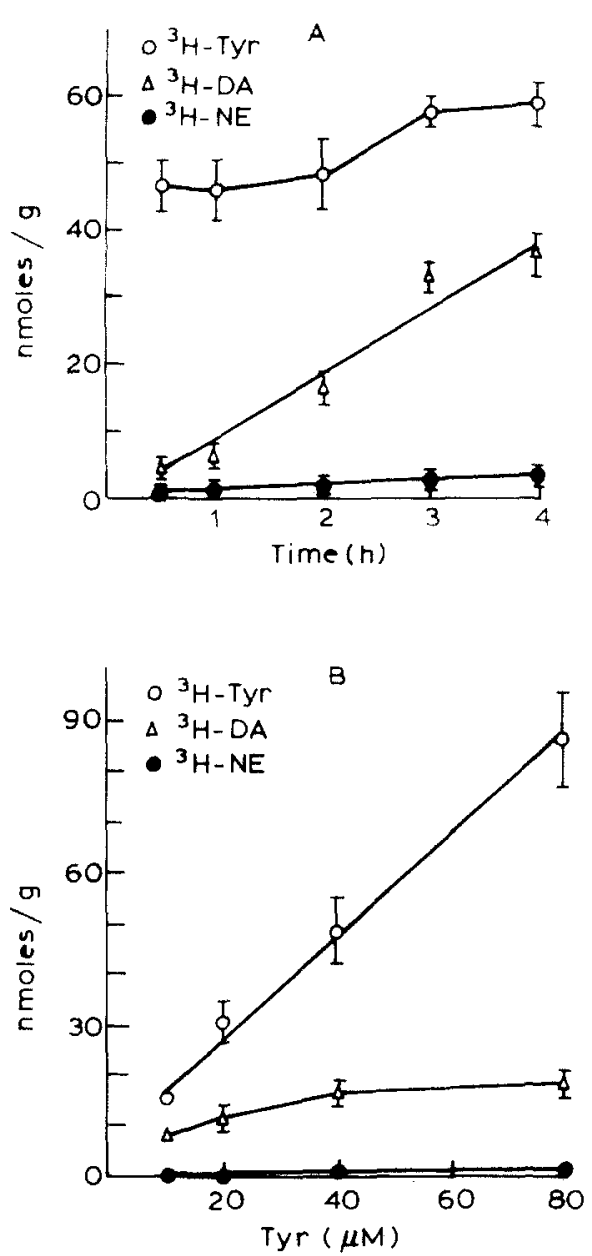

Fig. 2. A: time-course of $\left[{ }^{3} \mathrm{H}\right] \mathrm{CA}$ synthesis from $\left[{ }^{3} \mathrm{H}\right]$ tyrosine. Carotid bodies from cats breathing room air were incubated with $40 \mu \mathrm{M}\left[{ }^{3} \mathrm{H}\right]$ tyrosine in the presence of $10^{-4} \mathrm{M} \mathrm{MPH}_{4}$ and $10^{-3} \mathrm{M}$ ascorbic acid. At the end of the incubation period, $\left[{ }^{3} \mathrm{H}\right] \mathrm{DA},\left[{ }^{3} \mathrm{H}\right] \mathrm{NE}$ and $\left[{ }^{3} \mathrm{H}\right]$ tyrosine were separated by high-voltage paper electrophoresis. $\mathrm{B}$ : synthesis of $\left[{ }^{3} \mathrm{H}\right] \mathrm{CAs}$ as a function of $\left[{ }^{3} \mathrm{H}\right]$ tyrosine concentration in the incubation media; incubation conditions and measurement of $\left[{ }^{3} \mathrm{H}\right] \mathrm{CAs}$ as in $\mathrm{A}$. Data are means \pm S.E.M. of 5-8 carotid bodies.

ly counted and the resultant radioactivity taken as a direct measure of $\left[{ }^{3} \mathrm{H}\right] \mathrm{DA}$ release.

The release of labelled CAs is expressed in terms of basal, or control, release; the mean value for release from the control periods of two consecutive stimulus cycles was taken as basal release $/ 5 \mathrm{~min}$ during that intervening cycle. Any release above this basal level during the stimulus period was considered to be stimulus-related release. Basal versus stimulusrelated discharge from the $\mathrm{CSN}$ was evaluated in a similar manner.
RESULTS

Synthesis of $\left[{ }^{3} \mathrm{H}\right]$ catecholamines by the cat carotid body

The first group of experiments established the time-course of $\left[{ }^{3} \mathrm{H}\right] \mathrm{CA}$ synthesis from $40, \mu \mathrm{M}\left[{ }^{3} \mathrm{H}\right]$ tyrosine (Fig. 2A), a concentration similar to that present in cat plasma ${ }^{39}$. Under these conditions, synthesis of both $\left[{ }^{3} \mathrm{H}\right] \mathrm{DA}$ and $\left[{ }^{3} \mathrm{H}\right] \mathrm{NE}$ was linear up to $4 \mathrm{~h}$, indicating adequate availability of both precursor and cofactor. Near maximal accumulation of free $\left[{ }^{3} \mathrm{H} \mid \mathrm{ty}\right.$ rosine by the cat carotid body was achieved after 30 min of incubation, which was similar to that found for the rabbit ${ }^{11}$. The intracellular concentration of $\left[{ }^{3} \mathrm{H}\right]$ tyrosine at this point was estimated (assuming that $40 \%$ of the carotid body wet weight represents intracellular water) to be approximately $100 \mu \mathrm{M}$. which is saturating for tyrosine hydroxylase 23,32 .

The relationship between $\left[{ }^{3} \mathrm{H}\right]$ tyrosine concentration and $[3 \mathrm{H}] \mathrm{CA}$ synthesis was studied in carotid bodies incubated for $2 \mathrm{~h}$ with the tyrosine hydroxylase cofactor, 6- $\mathrm{MPH}_{4}$, at a concentration of $10+\mathrm{M}$. As shown in Fig. 2B, the synthesis of both $\left[{ }^{3} \mathrm{H}\right] \mathrm{DA}$ and $\left[{ }^{3} \mathrm{H}\right] \mathrm{NE}$ plateaued at approximately $40 \mu \mathrm{M}\left[{ }^{3} \mathrm{H}\right]$ tyrosine, as predicted from the data shown in Fig. $2 \mathrm{~A}$. The accumulation of free $\left[{ }^{3} \mathrm{H}\right]$ tyrosine by the tissues increased linearly with the media concentration.

\section{Effects of sympathectomy and CSN denervation on} $\left[{ }^{3} \mathrm{H}\right]$ catecholamine synthesis

Sympathetic nerve endings are known to be present in the carotid body ${ }^{24}$, and Table I (A) shows that following chronic sympathectomy (removal of the superior cervical ganglion 12-15 days prior to experimentation), there was a $40 \%$ reduction $(P<0.02)$ in $\left[{ }^{3} \mathrm{H}\right] \mathrm{NE}$ synthesis but no change in $\left[{ }^{3} \mathrm{H}\right] \mathrm{DA}$ synthesis. From these data and those presented in Fig. 2, the ratio for $\left[{ }^{3} \mathrm{H}\right] \mathrm{DA}$ vs $\left[{ }^{3} \mathrm{H}\right] \mathrm{NE}$ synthesis is about $20: 1$. Considering that the endogenous levels of DA and $\mathrm{NE}$ in the cat carotid body are similar ${ }^{15,37}$ (also unpublished data), our findings suggest a much slower turnover rate for NE than for DA in the parenchymal tissue of the carotid body. Additionally. since the endogenous content of NE is unchanged after sympathectomy (unpublished observations), these data would also indicate that the turnover rate of $\mathrm{NE}$ is higher for the sympathetic endings than for the glomus cells. In our previous studies with the rabbit, an 


\section{TABLE I}

Effects of sympathectomy and CSN denervation on the rate of $\left[{ }^{3} \mathrm{H}\right] \mathrm{CA}$ synthesis in cat carotid body

Superior cervical ganglia and CSNs were surgically removed 12-15 days prior to experimentation. Denervated carotid bodies and their corresponding contralateral controls were incubated for $3 \mathrm{~h}$ in $40 \mu \mathrm{M}\left[{ }^{3} \mathrm{H}\right]$ tyrosine, $10^{-4} 6-\mathrm{MPH}_{4}$ and $10^{-3} \mathrm{M}$ ascorbic acid. Data are means \pm S.E.M. of $6-8$ carotid bodies and are expressed as pmol/carotid body $/ 3 \mathrm{~h}$.

\begin{tabular}{llll}
\hline & {$\left[{ }^{3} \mathrm{H}\right] \mathrm{Ty}$} & $\left.{ }^{3} \mathrm{H}\right] \mathrm{DA}$ & $\left.{ }^{3} \mathrm{H}\right] \mathrm{NE}$ \\
\hline (A) & & & \\
$\quad$ Control & $23.8 \pm 3.9$ & $19.2 \pm 3.26$ & $1.1 \pm 0.40$ \\
Sympathectomy & $27.37 \pm 5.17$ & $18.0 \pm 5.62$ & $0.66 \pm 0.26^{*}$ \\
& & & \\
(B) & & & \\
Control & $17.2 \pm 2.82$ & $20.7 \pm 3.8$ & $1.0 \pm 0.18$ \\
Deafferentation & $26.6 \pm 5.94$ & $20.6 \pm 4.6$ & $1.5 \pm 0.15^{*}$
\end{tabular}

* $P<0.02$ (paired $t$-test).

$80 \%$ reduction in $\left[{ }^{3} \mathrm{H}\right] \mathrm{NE}$ synthesis was found for sympathectomized carotid bodies, with no change in $\left[{ }^{3} \mathrm{H}\right] \mathrm{DA}$ synthesis ${ }^{11}$. These results might mean that there is a more profuse sympathetic innervation of the carotid body in the rabbit than in the cat.

The effects of CSN denervation on [ $\left.{ }^{3} \mathrm{H}\right] \mathrm{CA}$ synthesis was also investigated because this nerve has been shown to exert trophic influences on the carotid body, including modifications of tyrosine hydroxylase activity and electrical properties of type I cells ${ }^{9,17}$. As shown in Table I (B), a 50\% increase in the rate of carotid body $\left[{ }^{3} \mathrm{H}\right] \mathrm{NE}$ synthesis $(P<0.02)$ was found $12-15$ days following CSN transection. This observation is consistent with our previous findings for the rabbit carotid body, where a $17 \%$ increase in [ $\left.{ }^{3} \mathrm{H}\right] \mathrm{NE}$ synthesis was observed ${ }^{11}$. The studies of Vazquez-Nin et al. ${ }^{40}$, which show that sympathetic nerve endings in the cat carotid body undergo sprouting after CSN transection, suggest a plausible explanation for the observed increase in $\left[{ }^{3} \mathrm{H}\right] \mathrm{NE}$ synthesis.

\section{Effects of hypoxia on $\left[{ }^{3} \mathrm{H} /\right.$ catecholamine synthesis} from $\left[{ }^{3} \mathrm{H}\right]$ tyrosine vs [ $\left.{ }^{3} \mathrm{H}\right] \mathrm{DOPA}$

Unanesthetized animals were exposed for $3 \mathrm{~h}$ in a chamber, either to $10 \% \mathrm{O}_{2}$ in $\mathrm{N}_{2}$ (hypoxia) or to room air (normoxia). The carotid bodies were quickly removed and incubated either for $3 \mathrm{~h}$ in $40 \mu \mathrm{M}$ $\left[{ }^{3} \mathrm{H}\right]$ tyrosine or for $2 \mathrm{~h}$ in $10 \mu \mathrm{M}\left[{ }^{3} \mathrm{H}\right] D O P A$ (see ref. 11). The results of these experiments are presented in Fig. 3A ([$\left.{ }^{3} \mathrm{H}\right]$ tyrosine) and Fig. 3B ([$\left.{ }^{3} \mathrm{H}\right]$ DOPA). The hypoxic carotid bodies incubated with $\left[{ }^{3} \mathrm{H}\right]$ tyrosine exhibited approximately a $100 \%$ increase in the rate of $\left[{ }^{3} \mathrm{H}\right] \mathrm{DA}$ synthesis $(P<0.01)$ but no change in $\left[{ }^{3} \mathrm{H}\right] \mathrm{NE}$ synthesis. Thus, the effect of hypoxia in increasing only the rate of $\left[{ }^{3} \mathrm{H}\right] \mathrm{DA}$ synthesis in the cat carotid body agrees with our previous findings for the rabbit ${ }^{13}$. We also observed a significant $(P<0.01)$ increase in the accumulation of free $\left[{ }^{3} \mathrm{H}\right]$ tyrosine in hypoxic carotid bodies compared to control organs. This increase in free $\left[{ }^{3} \mathrm{H}\right]$ tyrosine might have contributed to the observed increase in $\left[{ }^{3} \mathrm{H}\right] \mathrm{DA}$ synthesis, but this contribution should have been minimal because (1) there was no increase in $\left[{ }^{3} \mathrm{H}\right] \mathrm{NE}$ synthesis,
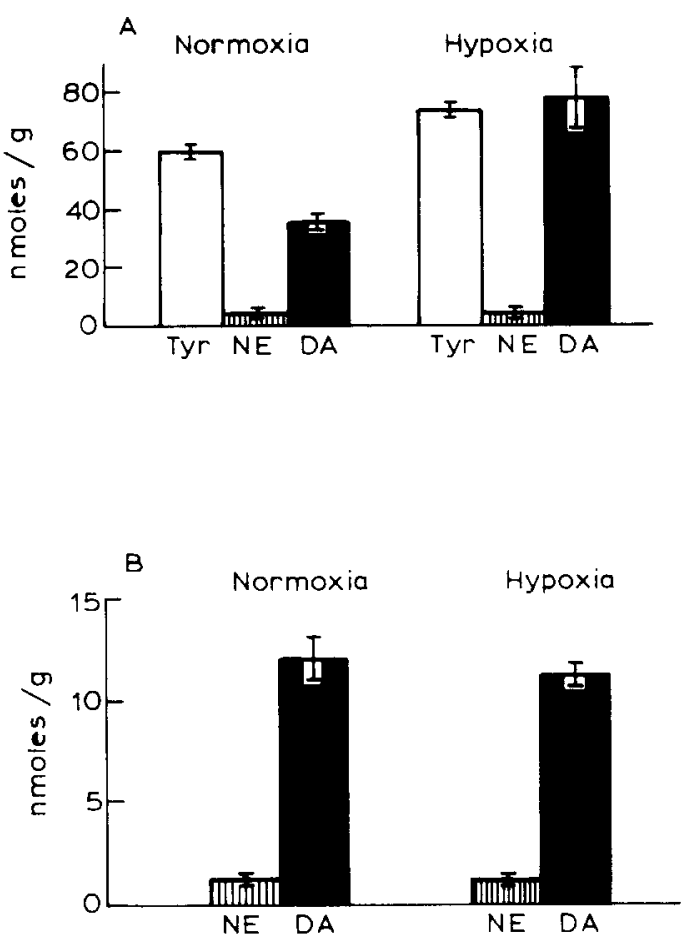

Fig. 3. Effects of hypoxic exposure $\left(10 \% \mathrm{O}_{2}\right.$ in $\left.\mathrm{N}_{2} ; 3 \mathrm{~h}\right)$ of the animals on the synthesis of $\left[{ }^{3} \mathrm{H}\right] \mathrm{CAs}$ by the cat carotid body. A: after the hypoxic episode, carotid bodies were removed from the animals and incubated in the presence of $40 \mu \mathrm{M}\left[{ }^{3} \mathrm{H}\right]$ tyrosine, $10^{-4} \mathrm{M} 6 \mathrm{MPH}_{4}$ and $10^{-3} \mathrm{M}$ ascorbic acid. The levels of $\left[{ }^{3} \mathrm{H}\right]$ tyrosine, $\left[{ }^{3} \mathrm{H}\right] \mathrm{DA}$ and $\left[{ }^{3} \mathrm{H}\right] \mathrm{NE}$ were determined as in Fig. 2. B: after identical hypoxic episodes, carotid bodies were incubated for $2 \mathrm{~h}$ with $10 \mu \mathrm{M}\left[{ }^{3} \mathrm{H}\right] \mathrm{DOPA}$. This incubation time and concentration were chosen because synthesis was linear for up to $4 \mathrm{~h}$ with as much as $60 \mu \mathrm{M}\left[{ }^{3} \mathrm{H}\right] \mathrm{DOPA}$. In both $\mathrm{A}$ and $\mathrm{B}$, normoxic animals were similarly exposed to room air in the chamber. Data are means \pm S.E.M. of at least 6 carotid bodies. In $\mathrm{A}$, tyrosine and $\mathrm{DA}$ in normoxia vs hypoxia are statistically ( $t$-test) different at the $P<0.01$ level 
(2) as shown in Fig. 2B, when carotid bodies were incubated with $80 \mu \mathrm{M}\left[{ }^{3} \mathrm{H}\right]$ tyrosine, the rate of $\left[{ }^{3} \mathrm{H}\right] \mathrm{CA}$ synthesis was not significantly increased despite a $100 \%$ increase in tissue levels of free $\left[{ }^{3} \mathrm{H}\right]$ tyrosine, and (3) a similar increase in $\left[{ }^{3} \mathrm{H}\right] \mathrm{DA}$ synthesis was observed in hypoxic rabbit carotid bodies without any increase in free $\left[{ }^{3} \mathrm{H}\right]$ tyrosine levels in the tissues. Thus, the specific increase in $\left[{ }^{3} \mathrm{H}\right] \mathrm{DA}$ synthesis after the hypoxic episode probably resulted from an increased release of endogenous DA during the hypoxic episode and subsequent removal of feedback inhibition exerted by DA at the level of tyrosine hydroxylase, the rate-limiting step in CA synthesis 13.30 .35 .42 . Consistent with this interpretation, our results showed that when the tyrosine hydroxylase step is obviated by incubation of the tissue with [ $\left.{ }^{3} \mathrm{H}\right] \mathrm{DOPA}$ instead of $\left[{ }^{3} \mathrm{H}\right]$ tyrosine (Fig. 3B), the hypoxic episode failed to produce any change in the rate of [ $\left.{ }^{3} \mathrm{H}\right] \mathrm{DA}$ synthesis; the same lack of effect of hypoxia was seen in rabbit carotid bodies incubated with $\left[{ }^{3} \mathrm{H}\right] \mathrm{DOPA}^{13}$, as well as in other tissues after physiologic stimulation ${ }^{36,42}$

\section{Effects of low oxygen on $[3 \mathrm{H} /$ catecholamine release and $C S N$ discharge}

In preliminary experiments, it was found that the basal efflux of $\left[{ }^{3} \mathrm{H}\right] \mathrm{DA}$ (synthesized from $\left[{ }^{3} \mathrm{H}\right]$ tyrosine) from cat carotid bodies exhibited two phases: one, lasting approximately $2 \mathrm{~h}$, in which the efflux decreased very rapidly, and another, which we followed for up to $8 \mathrm{~h}$, in which the basal efflux of [ $\left.{ }^{3} \mathrm{H}\right] \mathrm{DA}$ decreased very slowly with time. In studying the stimulus-induced release of $\left[{ }^{3} \mathrm{H}\right] \mathrm{CAs}$, the collection periods or 'stimulus cycles' (see Materials and Methods) were begun after the carotid bodies had first been perfused for $2 \mathrm{~h}$ with $100 \% \mathrm{O}_{2}$-equilibrated Tyrode. This precaution was taken in order to minimize possible errors arising from time-dependent processes (e.g. emptying of different $\left[{ }^{3} \mathrm{H}\right] \mathrm{CA}$ pools), rather than stimulus-related phenomena. Additionally, the order of presentation of the stimuli was randomized in the different experimens to avoid systematic errors arising from repeated placement of a given stimulus in the same region of the $\left[{ }^{3} \mathrm{H}\right] \mathrm{DA}$ decay curve ${ }^{14}$. Fig. 4 presents a typical experiment consisting of three stimulus cycles: the stimuli were $40 \%$, $20 \%$ and $10 \% \mathrm{O}_{2}$ in $\mathrm{N} 2$ for the first through third cycles, respectively, and the duration of stimulation

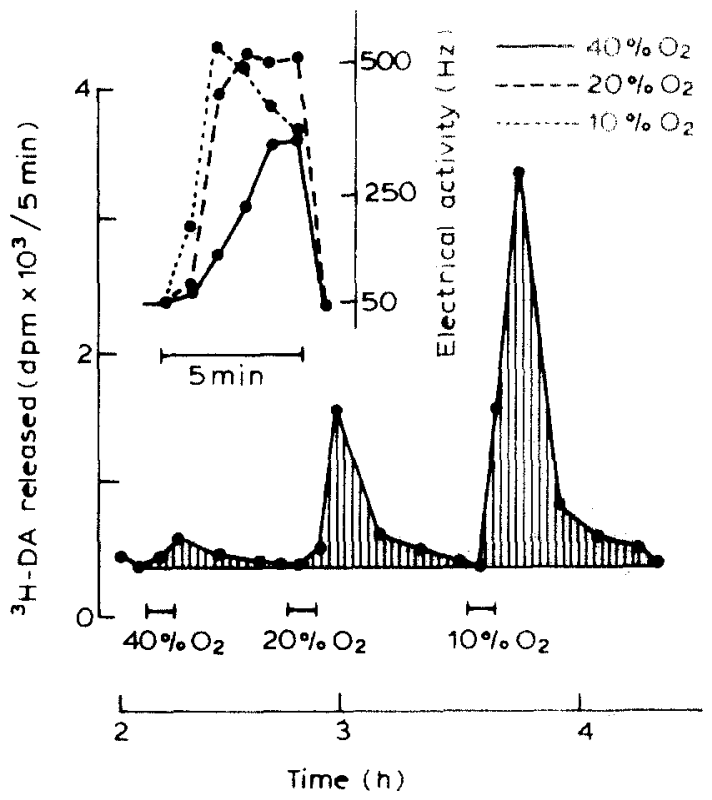

Fig. 4. The relationship between CSN discharge (inset) and [ $\left.{ }^{3} \mathrm{H}\right] \mathrm{DA}$ release from a carotid body previously incubated for $3 \mathrm{~h}$ in the presence of $\left[{ }^{3} \mathrm{H}\right]$ tyrosine $(40 \mu \mathrm{M}$; spec.act. $20 \mathrm{Cl}$ $\mathrm{mmol}), 10^{-4} \mathrm{M} 6 \mathrm{MPH}_{4}$ and ascorbic acid $\left(10^{-3} \mathrm{M}\right)$. Preparation was superfused with solutions equilibrated with low- $\mathrm{O}_{2-}^{-}$ gas mixtures $\left(40,20\right.$ and $10 \% \mathrm{O}_{2}$ in $\left.\mathrm{N}_{2}\right)$ at the times indicated in the figure. The stippled areas represent stimulus-induced release of $\left[{ }^{3} \mathrm{H}\right] \mathrm{DA}$.

was $5 \mathrm{~min}$ in each cycle. As evident from Fig. 4, the release of $\left[{ }^{3} \mathrm{H}\right] \mathrm{DA}$ was related to the strength of the low- $\mathrm{O}_{2}$ stimulus. CSN activity recorded during the stimulus period in each cycle is shown at the top of Fig. 4. Although the peak CSN discharge in response to $20 \%$ and $10 \% \mathrm{O}_{2}$ in $\mathrm{N}_{2}$ were similar, the time-topeak activity was longer with $20 \% \mathrm{O}_{2}$, and the response failed to adapt. Fig. 5 summarizes the characteristics of CSN response to low- $\mathrm{O}_{2}$ stimuli, and the relationship to $\left[{ }^{3} \mathrm{H}\right] \mathrm{DA}$ release (data are expressed as mean \pm S.E.M. of 8-15 responses). Fig. 5 A shows the time-to-peak CSN discharge from the onset of the stimulus, graphed as a function of the strength of the low- $\mathrm{O}_{2}$ stimulus. It can be seen that this time varies from as little as $1 \mathrm{~min}$ with the strongest stimulus, to more than 4 min for $50 \% \mathrm{O}_{2}$ in $\mathrm{N}_{2}$. This is similar to the results obtained by Eyzaguirre and Lewin ${ }^{8}$ with the in vivo cat carotid body preparation, where the rate of change of CSN discharge in response to hypoxia was dependent on the strength of the hypoxic stimulus; their times-to-peak responses were similar to those reported here. 
Fig. 5B shows the relationship between CSN activity and release of $\left[{ }^{3} \mathrm{H}\right] \mathrm{DA}$ for different low- $\mathrm{O}_{2}$ stimuli. Between $50 \%$ and $20 \% \mathrm{O}_{2}$ in $\mathrm{N}_{2}$ there was a close relationship between release and discharge, but with stronger stimuli $\left(10 \% \mathrm{O}_{2}\right.$ and $0 \% \mathrm{O}_{2}$ in $\left.\mathrm{N}_{2}\right)$, the release of [ $\left.{ }^{3} \mathrm{H}\right] \mathrm{DA}$ increased markedly without any significant further increase in CSN activity. This relationship is qualitatively similar to that observed with the rabbit carotid body, although in the rabbit the increase in $\left[{ }^{3} \mathrm{H}\right] \mathrm{DA}$ release and CSN activity was more closely related at the higher stimulus strengths ${ }^{14}$.

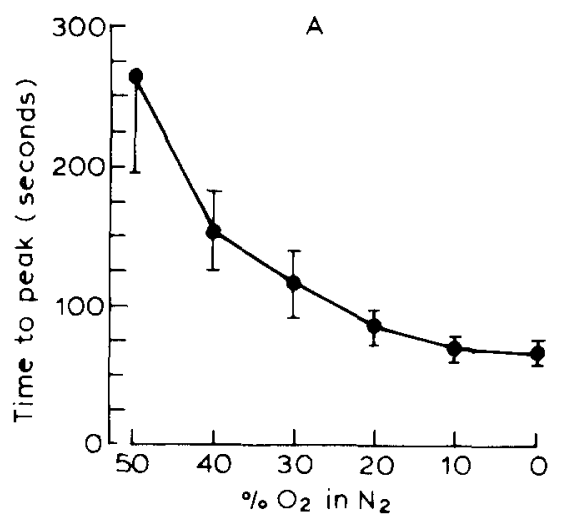

$B$

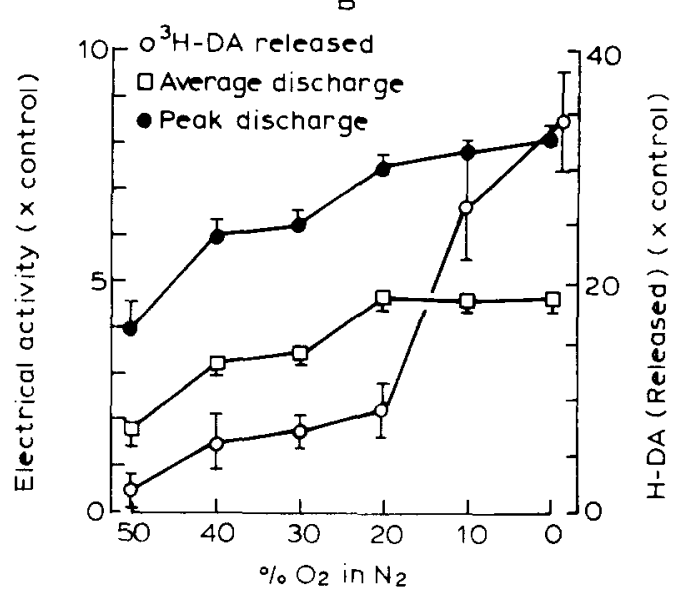

Fig. 5. Characteristics of CSN discharge and $\left[{ }^{3} \mathrm{H}\right] \mathrm{DA}$ release in response to hypoxic stimulation of the carotid body (data are means \pm S.E.M. of 8-15 responses to different low $-\mathrm{O}_{2}$ stimuli). A: time-to-peak CSN discharge in response to different low- $\mathrm{O}_{2}$ stimuli. B: relationship between $\left[{ }^{3} \mathrm{H}\right] \mathrm{DA}$ release and average vs peak CSN discharge in relation to the intensity of the low- $\mathrm{O}_{2}$ stimulus.

\section{DISCUSSION}

In the present study, we have described some characteristics of $\left[{ }^{3} \mathrm{H}\right] \mathrm{CA}$ synthesis and release in the in vitro cat carotid body preparation. We have found that synthesis of $\left[{ }^{3} \mathrm{H}\right] \mathrm{DA}$ and $\left[{ }^{3} \mathrm{H}\right] \mathrm{NE}$ from $\left[{ }^{3} \mathrm{H}\right]$ tyrosine was linear for up to $4 \mathrm{~h}$ and that the rate of synthesis plateaued when the media concentration of $\left[{ }^{3} \mathrm{H}\right]$ tyrosine reached $40 \mu \mathrm{M}$, a level similar to that found in cat plasma ${ }^{39}$. These results indicate that tyrosine concentration is probably not a limiting factor for CA synthesis in vivo in the cat carotid body.

Under resting conditions, the rates of $\left[{ }^{3} \mathrm{H}\right] \mathrm{DA}$ and $\left[{ }^{3} \mathrm{H}\right] \mathrm{NE}$ synthesis were approximately 10 and 0.5 $\mathrm{nmol} / \mathrm{g}$ tissue $/ \mathrm{h}$ (6.5 and $0.35 \mathrm{pmol} /$ carotid body $/ \mathrm{h})$, respectively, yielding a $\left[{ }^{3} \mathrm{H}\right] \mathrm{DA}:\left[{ }^{3} \mathrm{H}\right] \mathrm{NE}$ ratio of approximately 20 . The DA:NE ratio for endogenous CAs in the cat carotid body varies considerably from study to study (between 0.3 and 4.0 ; see ref. 12 for review), but whichever values are taken, our results clearly indicate a slower turnover for NE than DA in the cat carotid body. These data are in agreement with the observations of Belmonte et al. ${ }^{3}$, who found low levels of dopamine- $\beta$-hydroxylase in the cat carotid body, and with the recent studies of Starlinger et al. ${ }^{37}$, who described for this animal a very low rate for the in vivo conversion of tyramine to octopamine after inhibition of monoamine oxidase. Since this conversion is an index of dopamine- $\beta$-hydroxylase activity, the authors concluded that the high NE content must result from either high retention and/or low degradation of the amine, rather than from a high rate of synthesis. Moreover, it has been demonstrated $^{15}$ that exposure of cats to hypoxia resulted in decreased carotid body DA without any change in $\mathrm{NE}$ content, which also suggests a slow rate of $\mathrm{NE}$ utilization during hypoxia. Of course, the possibility does exist that the cat carotid body in vitro might not synthesize NE at the normal in vivo rate. BoadleBiber and Roth ${ }^{4}$ described decreased NE synthesis in vitro for the rat vas deferens, i.e. a higher DA:NE ratio for synthesis in vitro compared to in vivo. In the guinea pig, on the other hand, these authors showed that the DA:NE ratios were the same for both the in vitro and the in vivo preparations. It is noteworthy, however, that in their experiments ascorbic acid was absent from the in vitro incubation media. This substance is an important co-factor for the enzyme dopa- 
mine- $\beta$-hydroxylase, which converts DA to $\mathrm{NE}^{31}$, and thus, the discrepant ratios which they observed for the rat might have resulted from a lack of ascorbic acid. In our experiments, the incubation media always contained $1 \mathrm{mM}$ ascorbic acid, and thus the likelihood is small that the low NE synthesis which we observed with the in vitro cat carotid body preparation was due to a compromised synthetic machinery.

The effects of CSN denervation and sympathectomy on the rate of synthesis of $\left[{ }^{3} \mathrm{H}\right] \mathrm{CAs}$ in the cat carotid body are similar to our previous findings with the rabbit ${ }^{13}$, and with those of Hanbauer and Hellstrom for the rat ${ }^{18}$, i.e. no change in DA synthesis or content following either kind of denervation but a significant decrease in both NE synthesis and content after sympathectomy and a tendency towards their increase after CSN denervation.

The effects of hypoxia on $\left[{ }^{3} \mathrm{H}\right] \mathrm{CA}$ synthesis in the cat carotid body are also the same as those previously reported for the rabbit ${ }^{13}$. The specific increase in [ $\left.{ }^{3} \mathrm{H}\right] \mathrm{DA}$ synthesis suggests that NE may be contained in different glomus cells than DA. In this regard, it is interesting to note that two subpopulations of type I cells have been distinguished on the basis of ultrastructural $^{20.25}$, cytochemical ${ }^{19,38}$ and immunohistochemical studies ${ }^{5}$, suggesting that NE may be present in only one of these cell types. However, the existence of two distinct subpopulations of type I cells in the carotid body has been a controversial issue, and this problem remains largely unresolved at the present time (see ref. 12).

The relationship between $\left[{ }^{3} \mathrm{H}\right] \mathrm{DA}$ release and $\mathrm{CSN}$ activity at weak to moderate levels of low $-\mathrm{O}_{2}$ stimulation suggests that endogenous DA may participate in the genesis of the chemoreceptor re-

\section{REFERENCES}

1 Barchas, J.D., Akil, H., Elliot, G.R., Holman, R.B. and Watson, S.J., Behavioral neurochemistry: neuroregulators and behavioral states, Science, 200 (1978) 964-973.

2 Belmonte, C. and Gonzalez, C., Mechanisms of chemoreception in the carotid body: possible models. In H. Acker and R.G. O'Regan (Eds.), Physiology of the Peripheral Arterial Chemoreceptors, Elsevier, Amsterdam, 1983, pp. 197-220.

3 Belmonte, C., Gonzalez, C. and Garcia, A., Dopamine beta hydroxylase activity in cat carotid body. In H. Acker, S. Fidone, D. Pallot, C. Eyzaguirre, D.W. Lubbers and R.W. Torrance (Eds.), Chemoreception in the Carotid sponse. Although stronger stimuli resulted in disproportionately small increases in CNS discharge in comparison to the large increases in $[3 \mathrm{H} \mid \mathrm{DA}$ release. this observation might be due in part to the following: (1) shorter duration of action for the weaker stimuli due to less steep gradients for excitation of the chemoreceptors (see time-to-peak CSN response is strength of low- $\mathrm{O}_{2}$ stimulus, Fig. 5A). (2) occlusion of the recorded nerve spikes with stronger stimuli in our whole nerve recordings, and (3) saturation of the neural component of the receptor response and adaptation of the chemoreceptors at high stimulus strengths.

In conclusion, our study of the synthesis and release of $\left[{ }^{3} \mathrm{H}\right] \mathrm{CAs}$ in the cat carotid body has shown that the basic neurochemical aspects of [ $\left.{ }^{3} \mathrm{H}\right] \mathrm{DA}$ metabolism in this organ are similar to those described earlier for the rabbit and rat carotid body. These findings help resolve the controversy regarding the effects of hypoxia on the release of DA in the cat (see Introduction) and suggest that the apparent species differences observed in pharmacological experiments do not accurately reflect the physiological function of this amine. It is likely, therefore, that in all these species this putative neurotransmitter may play analogously important roles in the chemoreception process.

\section{ACKNOWLEDGEMENTS}

Supported by a grant from the C.A.I.C.T. of Spain and USPHS Grants NS-12636 and NS-07938. We gratefully acknowledge the technical assistance of Mr. Larry Jones and the efforts of Ms. Vicki Skelton in the preparation of the manuscript.
Body, Springer, Berlin, 1977, pp. 99-105.

4 Boadle-Biber, M.C. and Roth, R.H., Formation of dopamine and noradrenaline in rat vas deferens: comparison with guinea pig vas deferens, $B r . J$. Pharmacol. 55 (1975). $73-78$.

5 Chen, J.L. and Yates, R.D., Two types of glomus cell in the rat carotid body as revealed by alpha-bungarotoxin binding, J. Neurocytol., 13 (1984) 281-302.

6 Docherty, R.J. and McQueen, D.S., The effects of acetylcholine and dopamine on carotid chemosensory activity in the rabbit, J. Physiol. (London), 288 (1979) 411-423.

7 Donnelly, D.F., Smith, E.J. and Dutton, R.E., Neural response of carotid chemoreceptors following dopamine blockade, J. Appl. Physiol. 50 (1981) 172-177. 
8 Eyzaguirre, C. and Lewin, J., Chemoreceptor activity of the carotid body of the cat, J. Physiol. (London). 159 (1961) 238-250.

9 Eyzaguirre, C., Monti-Bloch, L. and Hayashida, Y., Effects of temperature on denervated carotid body (glomus) cells. Brain Research, 279 (1983) 282-285.

10 Eyzaguirre, C. and Zapata, P., A discussion of possible transmitter or generator substances in carotid body chemoreceptors. In R.W. Torrance (Ed.), Arterial Chemoreceptors, Blackwell, Oxford, 1968, pp. 213-251.

11 Fidone, S.J. and Gonzalez, C., Catecholamine synthesis in rabbit carotid body in vitro, J. Physiol. (London), 333 (1982) 69-79.

12 Fidone, S.J. and Gonzalez, C.. Initiation and control of chemoreceptor activity in the carotid body. In J.G. Widdicombe (Ed.), Handbook of Physiology, The Respiratory System II, Amer. Physiol. Soc., Washington, DC, in press.

13 Fidone, S.J., Gonzalez, C. and Yoshizaki, K., Effects of hypoxia on catecholamine synthesis in rabbit carotid body in vitro, J. Physiol. (London), 333 (1982) 79-93.

14 Fidone, S.J., Gonzalez, C. and Yoshizaki, K. Effects of low oxygen on the release of dopamine from the rabbit carotid body in vitro, J. Physiol. (London), 333 (1982) 93-110.

15 Fitzgerald, R.S., Garger, P., Haner, M.C., Raff, M. and Fetcher, L., Effect of hypoxia and hypercapnia on catecholamine content in cat carotid body, J. Physiol. Respirat. Environ. Exercise Physiol., 54 (1983) 1408-1413.

16 Fleming, R.M. and Clark, W.G., Quantitative thin-layer chromatographic estimation of labelled dopamine and norepinephrine, their precursors and metabolites, J. Chromatog., 52 (1970) 305-312.

17 Gonzalez, C., Kwok, Y., Gibb, J.W. and Fidone, S.J., Reciprocal modulation of tyrosine hydroxylase activity in rat carotid body, Brain Research, 172 (1979) 572-576.

18 Hanbauer. I. and Hellstrom, S., The regulation of dopamine and noradrenaline in the rat carotid body and its modification by denervation and by hypoxia, J. Physiol. (London), 282 (1978) 21-34.

19 Hansen, J.T., Chemoreceptor nerve and type A glomus cell activity following hypoxia, hypercapnia or anoxia: a morphological study in the rat carotid body, J. Ultrastruct. Res., 77 (1981) 189- 198.

20 Hellstrom, S., Morphometric studies of dense-cored vesicles in type I cells of rat carotid body, $J$. Neurocytol., 4 (1975) $77-86$

21 Heymans, C., Bouckaert, J.J. and Doutrebande, L., Sinus carotidien et reflexes respiratoires. II. Infuences respiratoires reflexes de l'acidose, de l'alcalose, de l'anhydride carbonique, de l'ion hydrogen et de l'anoxemie: Sinus carotidiens et echanges respiratoires dans les poumons et au dela des poumons, Arch. Int. Pharmacodyn. Ther., 39 (1930) 400-408.

22 Leitner, L.M., Roumy, M. and Verna, A., In vitro recording of chemoreceptor activity in catecholamine-depleted rabbit carotid bodies, Neuroscience, 10 (1983) 883-891.

23 Levitt, M., Spector, S., Sjodersma, A. and Underfriend, S., Elucidation of the rate-limiting step in norepinephrine biosynthesis in the perfused guinea-pig heart, J. Pharmacol. Exp. Ther., 148 (1965) 1-8.

24 McDonald, D.M., Peripheral chemoreceptors: structurefunction relationships of the carotid body. In T.F. Hornbein (Ed.), The Lung Biology in Health and Disease, Vol. X, The Regulation of Breathing, Marcel Dekker, New York, 1981 , pp. $105-193$

25 McDonald, D.M. and Mitchell, R.A., The innervation of glomus cells, ganglion cells and blood vessels in the rat ca- rotid body: a quantitative ultrastructural analysis, $J$. Neurocytol., 4 (1975) 177-230.

26 McLennan, H., Synaptic Transmission, Saunders, Philadelphia, 1983.

27 McQueen, D.S., Pharmacological aspects of putative transmitters in the carotid body. In H. Acker and R.G. O'Regan (Eds.), Physiology of the Peripheral Arterial Chemoreceptors, Elsevier, Amsterdam, 1983. pp. 149-195.

28 Mills, E. and Slotkin, T.A.. Catecholamine content of the carotid body in cats ventilated with $8-40 \%$ oxygen, Life Sci., 16(1975) 1555-1562.

29 Monti-Bloch, L. and Eyzaguirre, C. A comparative physiological and pharmacological study of cat and rabbit carotid body chemoreceptors. Brain Research, 193 (1980) $449-470$.

30 Murrin, L.C. and Roth, R.H., Dopaminergic neurons: effects of electical stimulation on dopamine biosynthesis, Mol. Pharmacol., 12 (1976) 463-475.

31 Nagatsu, T., Biochemistry of Catecholamines. The Biochemical Method, University Park Press, Tokyo, 1973.

32 Nagatsu, T.. Levitt, M. and Underfriend, S., Tyrosine hydroxylase: the initial step in norepinephrine biosynthesis. J. Biol. Chem., 239 (1964) 2910-2917.

33 Nolan, W.F., Donnelly, D.F., Smith, E.J. and Dutton. R.E., Inhibition of carotid chemoreception by haloperidol in vitro, Fed. Proc. 43 (1984) 813.

34 Orrego, F., Criteria for the identification of central neurotransmitters and their application to studies with some nerve tissue preparations in vitro, Neuroscience, 4 (1979) $1037-1057$.

35 Roth, R.H., Stjarne, L. and Euler, V.S., Acceleration of noradrenaline biosynthesis by nerve stimulation, Life Sci. 5 (1966) $1071-1075$.

36 Sedvall, G.C. and Kopin, I.J., Acceleration of norepinephrine synthesis in the rat submandibulary gland in vivo during sympathetic nerve stimulation. Life Sci., 6 (1967) $45-51$.

37 Starlinger, H.. Acker, H. and Heinrich, R., Dopaminebeta-hydroxylase activity of the cat carotid body under different arterial $\mathrm{O}_{2}$ and $\mathrm{CO}$, conditions. J. Neurochem., 41 (1983) $1533-1537$

38 Stensaas, L.J., Stensaas, S.S., Gonzalez. C. and Fidone, S.J., Analytical electron microscopy of granular vesicles in the carotid body of the normal and reserpinized cat. In $C$. Belmonte, D. Pallot, H. Acker and S. Fidone (Eds.), Arterial Chemoreceptors, Leicester University Press, Leicester, U.K. 1981 . pp. 176-186.

39 Tallan. H.H., Moore, S. and Stein. W.H., Studies on the free amino acids and related compounds in the tissues of the cat, J. Biol. Chem., 211 (1954) 927-939.

40) Vazquez-Nin. G.H., Costero, I., Echevarria, O.M., Aguilar, R. and Barroso-Moguel, R., Innervation of the carotid body. An experimental quantitative study, Acta Nat., 102 (1978) 12-28.

41 Verna, A., Ultrastructure of the carotid body in mammals, Int. Rev. Cytol., 60 (1979) 27I-330.

42 Weiner, N. and Rabadjija, M., The effect of nerve stimulation on the synthesis and metabolism of norepinephrine in the isolated guinea-pig hypogastric nerve vas deferens preparation, J. Pharmacol. Exp. Ther., 160 (1968) 61-71.

43 Zapata, P., Effects of dopamine on carotid chemo- and baroreceptors in vitro. J. Physiol. (London), 244 (1975) $235-251$.

44 Zapata, P., Hess, A., Bliss, E.L. and Eyzaguirre, C., Chemical electron microscopic and physiological observations on the role of catecholamines in the carotid body, Brain Research, 14 (1969) 473-498. 